\title{
Carbosulfan-induced oxidative damage following subchronic exposure and the protective effects of $\mathrm{N}$-acetylcysteine in rats
}

\author{
Ines El-Bini Dhouib, Alya Annabi, Aicha Jrad, Narges El-Golli, Najoua Gharbi, Mohamed M. \\ Lasram and Saloua El-Fazaa
}

Laboratory of Aggression Physiology and Endocrine Metabolic Studies, Department of Biology, Faculty of Sciences, Tunis, Tunisia

\begin{abstract}
Carbosulfan (CB)-induced oxidative stress leads to the inevitable accumulation of free radicals and eventual alteration of antioxidant enzymes in various biological systems. The present study is designed to investigate the preventive effect of N-acetylcysteine (NAC) on carbosulfaninduced hepatic and renal dysfunction in rats. Rats exposed to $\mathrm{CB}$ and NAC were examined for toxicity by assessing various biochemical alteration and stress markers including in liver and kidney. Significant increases of blood alanine aminotransferase (ALT), alkaline phosphatase (ALP), gamma glutamyltransferase (GGT), creatinine and urea were detected in CB-treated rats. In addition, the levels of antioxidative enzymes such as catalase (CAT), superoxide dismutase (SOD) and reduced glutathione (GSH) also were assessed. According to the results, rats exposed to carbosulfan showed a significant increase in the accumulation of stress markers and an alteration in the antioxidative enzymes activity, when compared to their respective controls. Interestingly, administration of NAC to CB-treated rats attenuates the toxicity of this compound, objectified by biochemical and oxidative improvement of liver and kidney. Thus, the present study reports for the first time that NAC could be a promising therapeutic agent against CB-induced oxidative stress.
\end{abstract}

Key words: N-acetylcysteine - Carbosulfan — Liver - Kidney - Oxidative stress

Abbreviations: AChE, acetylcholinesterase; BChE, butyrylcholinesterase; CAT, N-acetylcysteine; $\mathrm{CB}$, carbosulfan-treated group; CB-NAC, NAC and carbosulfan-treated group; CTR, control group; GSH, reduced glutathione; NAC, N-acetylcysteine; SOD, superoxide dismutase.

\section{Introduction}

Anti-cholinesterase agents, also called acetylcholinesterase (AChE) inhibitors, are widely used in agriculture and medical treatment. Anti-cholinesterase pesticides mainly include organophosphates such as malathion as well as carbamates such as carbofuran and carbosulfan. The acute toxicity of these pesticides has been well documented (de Silva et al. 1992; Gupta 1994; Smulders et al. 2003; Raheja and Gill 2007; Lasram et al. 2009, 2014a). Liver, which is the main organ responsible for metabolism, is a common target of

Correspondence to: Ines El-Bini Dhouib, Laboratory of Aggression Physiology and Endocrine Metabolic Studies, Department of Biology, Faculty of Sciences, Tunis, Tunisia

E-mail: inesbini@yahoo.fr pesticide toxicity (Celik et al. 2009). Subchronic exposures to carbamates pesticides could induce hepato-nephrotoxicity with oxidative stress as the main mechanism (Kamboj et al. 2006; Binukumar et al. 2010).

In recent years, several reports have suggested that carbamates pesticides cause oxidative stress, characterized by exposure to excessive reactive oxygen species (ROS) (Durak et al. 2009; Eraslan et al. 2009). It has been shown that oxidative stress, which is known to be involved in the pathogenesis of several diseases, has been described in acute and chronic exposure to carbamates pesticides (Gupta 1994). The body has developed several defence mechanisms against oxidative damage. These defence mechanisms are composed of enzymatic and non-enzymatic systems (Eraslan et al. 2009). The enzymatic mechanism is made of free radical scavengers like catalase (CAT), superoxide dismutase (SOD) and 
glutathione-S-transferase (GSH) (Khan and Kour 2007; Durak et al. 2009).

The non-enzymatic mechanism involves certain endogenous compounds found in the body and certain exogenous compounds taken into the body (vitamins $\mathrm{E}$ and $\mathrm{C}$, flavonoids, etc.) (Eraslan et al. 2009; Uzun et al. 2010). It is reported that carbosulfan enhance the production of ROS, and it alters the enzyme activities associated with antioxidant defence mechanisms in the spleen of male Wistar rats (ElBini Dhouib et al. 2014).

Antioxidant drugs are becoming increasingly popular in oxidative stress-related disorders and hold promise as therapeutic agents (Borgstrom et al. 1986). N-acetylcysteine (NAC) acts as an antioxidant by restoring the pool of intracellular reduced glutathione, which is often depleted as a consequence of increased status of oxidative stress and inflammation (Grinberg et al. 2005). Furthermore, NAC also has reducing and antioxidant properties, acting as a direct scavenger of ROS (Sadowska et al. 2007). Therefore, considering that carbosulfan toxicity is associated with behavioral impairments and that NAC has important antioxidant actions, the aim of this study was to investigate the effects of this compound on liver and kidney function as well as oxidative stress in tissue structures of carbosulfanexposed rats.

\section{Materials and Methods}

\section{Animals}

Rats (Wistar, 100-150 g of weight and 45 days of age) procured from Tunisian Society of Pharmaceutical Industries, divided into two groups, and housed two per cage in sterile plastic cage. The vivarium was maintained under normal day/night schedule (12 h light/12 h dark cycles) at room temperature $25 \pm 1^{\circ} \mathrm{C}$. Balanced food and water were given to the animals ad libitum. All the procedures were in accordance with Guidelines for Ethical Conduct in the Care and Use of Animals.

\section{Chemical}

Carbosulfan was provided by Tunisian Ministry of Agriculture; before use carbosulfan was dissolved in corn oil for a final concentration $25 \mathrm{mg} / \mathrm{ml}$.

\section{Treatment schedule}

A total of 36 animals were randomized into 3 groups of 12 rats each and were treated as below for 30 consecutive days. Carbosulfan or vehicle (corn oil) was administered in the morning (between 09:00 and 10:00 h) to non-fasted rats.
The day of the first exposure to carbosulfan was delineated as experimental day 1 .

Control (CTR) group: One milliliter of corn oil at a dose per day was given via oral gavage to rats once a day.

Carbosulfan-treated (CB) group: Carbosulfan was given at the dose of $25 \mathrm{mg} / \mathrm{kg}$ of body weight (b.w.) dissolved in total volume of $1 \mathrm{ml}$ of corn oil once a day during 30 days.

Carbosulfan + NAC-treated (CB-NAC) group: Rats received carbosulfan ( $25 \mathrm{mg} / \mathrm{kg}$ of b.w.) once a day and NAC $(2 \mathrm{~g} / \mathrm{l})$ dissolved in drinking water during 30 days.

The choice of carbosulfan dose was based on previous works of our group (El-Bini Dhouib et al. 2014) and corresponds to an acceptable dose that did not cause any sign of toxicity until the end of the experiment period. The used dose of carbosulfan is calculated directly from commercial grade and corresponds to 1/10 LD50 (International Programme on Chemical Safety (IPCS), 1996).

The dose of NAC used in this study $(2 \mathrm{~g} / \mathrm{l})$ was selected on the basis of previously published reportssuggesting that NAC was not toxic to humans or animals at this dose (Ortolani et al. 2000). Furthermore, NAC does not show any signs of toxicity at doses even higher than the one administered in the present study (El Midaoui et al. 2008).

\section{Body weight and blood collection}

Body weight changes of male rats were recorded daily during the experimental period (30 days). At the end of this period, blood samples were withdrawn from the animals under ether anaesthesia by puncturing the retro-orbital venous plexus of the animals with a fine sterilized glass capillary. Blood was collected into heparinized tubes and non-heparinized tubes and left for $20 \mathrm{~min}$ at room temperature. Then tubes were centrifuged at $3000 \times g$ for $10 \mathrm{~min}$ to separate the plasma or the serum. After that, the rats were sacrificed by cervical dislocation. Liver and kidneys of male and female rats were quickly removed and weighted individually. Then, the organ/ body weight ratio was calculated.

\section{Clinical hematological leucocytes}

Blood samples were collected into tubes with anticoagulant (EDTA) and immediately analyzed for hematological parameter: the white blood cells (WBC) using an automatic hematological assay analyzer (BC-2800 VET Mindray Auto Hematology Analyzer, Mindray, China).

\section{Plasma biochemical parameters}

Heparin was used as an anticoagulant and plasma samples were obtained by centrifugation at $3000 \times g$ for $10 \mathrm{~min}$ and stored at $-60^{\circ} \mathrm{C}$. Stored plasma samples wereanalyzed for 
total protein (TP) by the Biuret method according to Henry et al. (1978).

Glucose was measured by the glucose oxidase and peroxidase method using quinoneimine as a chromogen. The amount of plasma glucose is related to the amount of quinoneimine, which is measured spectrophotometrically at $505 \mathrm{~nm}$ (Lott and Turner 1975).

The activities of cellular enzymes such as aminotransferases (AST and ALT); lactate deshydrogenase (LDH); alkaline phosphatase (ALP) and acide phosphatase (ACP) were assessed with commercially available diagnostic kits supplied by Biomaghreb Laboratoires (Tunisia). Enzyme activity was expressed in International Units per liter (U/l).

Albumin (A) concentration was determined by the method of Westgard and Poquette (1972). Globulin (G) concentration was calculated as the difference between total protein and albumin (Lowry et al. 1951).

For determination of serum total cholesterol (TC) and triglyceride (TG) concentrations, the corresponding diagnostic kits, set by Biomaghreb Laboratories (Tunisia) were used according to the instructions of the manufacturer.

Urea and creatinine levels were determined by the methods of Fawcett and Scott (1960), Barham and Trinder (1972) and Bartels et al. (1972).

\section{Hepatic glycogen dosage}

Glycogen content was determined using the technique of Good et al. (1933). Briefly, $0.5 \mathrm{~g}$ of liver was extracted with $3 \mathrm{ml}$ of $30 \% \mathrm{KOH}$, incubated for $30 \mathrm{~min}$ at $100^{\circ} \mathrm{C}$, cooled and brought to acid $\mathrm{pH}$ by addition of $20 \%$ trichloroacetic acid. Precipitated protein was removed by centrifugation for $10 \mathrm{~min}$ at $3000 \times g$. Glycogen was precipitated by ethanol then weighted. The results are expressed in gram of glycogen per $100 \mathrm{~g}$ of liver.

\section{Tissue preparation}

Liver and kidneys were immediately removed, weighed and washed using chilled saline solution. Tissues were minced and homogenized (10\% w/v), separately, in ice-cold $1.15 \%$ in potassium phosphate buffer ( $\mathrm{pH}$ 7.4) in a Potter-Elvehjem type homogenizer. The homogenate was centrifuged at $10,000 \times \mathrm{g}$ for $20 \mathrm{~min}$ at $4^{\circ} \mathrm{C}$, and the resultant supernatant was used for enzyme assays. Protein concentrations in tissue were determined by the Coomassie reagent using serum bovine albumin as a standard (Bradford 1976).

\section{Lipid peroxidation and Antioxidant enzymes}

Malondialdehyde (MDA), as a marker for lipid peroxidation (LPO), was determined in serum by the double heating method of Begue and Aust (1978). The principle of the method is based on spectrophotometric measurement of the color produced during the reaction of thiobarbituric acid (TBA) with MDA. For this purpose, $2.5 \mathrm{ml}$ of $100 \mathrm{~g} / \mathrm{l}$ trichloroacetic acid (TCA) solution was added into $0.5 \mathrm{ml}$ tissus homogenate in a centrifuge tube and placed in a boiling water bath for $15 \mathrm{~min}$. After cooling under tap water, the mixture was centrifuged at $3000 \times g$ for $10 \mathrm{~min}$, and $2 \mathrm{ml}$ of the supernatant was transferred into a test tube containing $1 \mathrm{ml}$ of $6.7 \mathrm{~g} / \mathrm{l} \mathrm{TBA}$ solution and placed again in a boiling water bath for $15 \mathrm{~min}$. The solution was then cooled under tap water and its absorbance was measured spectrophotometrically at $532 \mathrm{~nm}$. The concentration of MDA was calculated by the absorbance coefficient of MDA-TBA complex $\left(1.56 \times 10^{5} \mathrm{M} / \mathrm{cm}\right)$ and expressed in $\mathrm{nmol} / \mathrm{ml}$.

Butyrylcholinesterase activity was determined spectrophotometrically by the modified Ellman's method using S-butyrylthiocholine iodide as substrate and 5,5-dithiobis, 2-nitrobenzoate (DTNB) as a chromogen (Ellman et al. 1961). Enzyme activity was expressed as nmoles of thiocholine-DTNB conjugate formed per minute per mg of protein.

Determination of thiol group's concentration is based on the method of $\mathrm{Hu}$ and Dillard (1994). Cellswere added to $0.25 \mathrm{M}$ base Tris and $20 \mathrm{mM}$ EDTA (ethylene tetra acetic acid) $\mathrm{pH}$ 8.2. Then, the mixture was vortexed and its absorbance was determined at $412 \mathrm{~nm}$. The first value was noted A1. After that, $10 \mathrm{mM}$ DTNB were added and incubated for an incubation period of $15 \mathrm{~min}$ and a new value A2 was determined. The white tube of DTNB contains only DTNB and buffer; its absorbance value is noted as B. We calculated the concentration of thiol groups (T-SH) per tube by using this equation expression: $\left(\mathrm{A}_{2}-\mathrm{A}_{1}-\mathrm{B}\right) \times 1.57 \mathrm{mM}$. Total glutathione (GSH) content in tissue was measured by the method of Tietze (1969) using dithionitrobenzene and expressed as $\mathrm{mmol} / \mathrm{ml}$.

The measurement of SOD was based on the principle in which xanthine reacts with xanthine oxidase to generate superoxide radicals which react with 2-(4-iodophenyl)-3(4-nitrophenol)-5-phenyltetrazolium chloride forming a red formazan dye. The SOD activity was then measured by the degree of inhibition of this reaction at $560 \mathrm{~nm}$ (Misra and Fridovich 1972). SOD activity was expressed in $\mu \mathrm{mol} / \mathrm{min} /$ mg protein. Hydrogen peroxide $\left(\mathrm{H}_{2} \mathrm{O}_{2}\right)$ decomposition by CAT enzyme was monitored kinetically at $240 \mathrm{~nm}$. One unit of activity is equal to the micromole of $\mathrm{H}_{2} \mathrm{O}_{2}$ degraded per minute per milligram of protein (Aebi 1984).

\section{Statistical analysis}

Data were statistically analyzed using the Student $t$-test to determine significant differences between different groups; $p$ values less than 0.05 were considered significant. The values were expressed as means $\pm \mathrm{SD}$. 
Table 1. Body weight, tissues weight and tissues index (organ weight/body weight $\times 100$ ) of experimental animals

\begin{tabular}{|c|c|c|c|}
\hline & CTR & $\mathrm{CB}$ & CB-NAC \\
\hline Initial body weight (g) & $152.41 \pm 3.94$ & $155.66 \pm 5.84$ & $158.33 \pm 4.82$ \\
\hline Final body weight (g) & $235.25 \pm 4.03$ & $221.75 \pm 4.58^{*}$ & $213.41 \pm 3.84^{\star, \#}$ \\
\hline Mass gain $(\mathrm{g})$ & $62.83 \pm 3.64$ & $46.08 \pm 5.99^{*}$ & $45.08 \pm 2.69^{*, \#}$ \\
\hline Food intake (g/kg b.w./day) & $94.606 \pm 3.422$ & $75.375 \pm 2.758^{\star}$ & $66.483 \pm 0.956^{*}$ \\
\hline Water intake (ml/kg b.w./day) & $88.627 \pm 2.059$ & $81.07 \pm 2.277^{\star}$ & $78.62 \pm 1.991^{*}$ \\
\hline Energy intake $(\mathrm{kcal} / \mathrm{kg} / \mathrm{j})$ & $330.062 \pm 11.93$ & $262.971 \pm 9.622^{*}$ & $221.947 \pm 3.33^{*}$ \\
\hline Liver weight $(\mathrm{g})$ & $6.89 \pm 0.41$ & $9.06 \pm 0.22^{*}$ & $6.152 \pm 0.255^{\#}$ \\
\hline Kidney weight (g) & $0.65 \pm 0.033$ & $0.96 \pm 0.23^{*}$ & $0.645 \pm 0.024^{\#}$ \\
\hline
\end{tabular}

CTR, control group; CB, carbosulfan-treated group; CB-NAC, animals received carbosulfan and NAC. Values are expressed as mean \pm SD $(n=12) ;{ }^{*}$ significantly different from the control group $(p<0.05) ;{ }^{*}$ significantly different from the CB group $(p<0.05)$.

\section{Results}

\section{Physical observation}

Obvious signs and symptoms of toxicity were not observed in the rats with any of the pesticide treatments. Also none of the animals died.

\section{Body weight and mass gain}

The changes in the body and organs weight of control and experimental rats during experimental period were given in Table 1. There was no significant change in the initial body weight between the groups whereas there was a significant decrease in the final body weight and mass gain and a significant increase in liver and kidney weight of carbosulfanadministered rats when compared to CTR rats. NAC-treated rats increase final body weight and mass gain and decrease liver and kidney weight after carbosulfan administration.
However, it was important to indicate that death was not observed in any of the experimental groups during the experimental period. Also, no clinical signs of carbosulfan poisoning were observed among treated rats.

\section{Changes in plasma glucose and hepatic glycogen rate}

Carbosulfan at dose of $25 \mathrm{mg} / \mathrm{kg}$ induced a significant increase in blood glucose (144.04\%). The hepatic glycogen level was considerably decreased (22.94\%). A significant decrease was glycaemia in CB-NAC group compared with CB group by $42.43 \%$. In addition, hepatic glycogen rate increased in CB-NAC group compared with CB group by 135.09\% (Figure 1).

\section{Changes in lipid status}

In addition, carbosulfan increased significantly plasma cholesterol and triglycerides content (Figure 2). Interestingly,
A

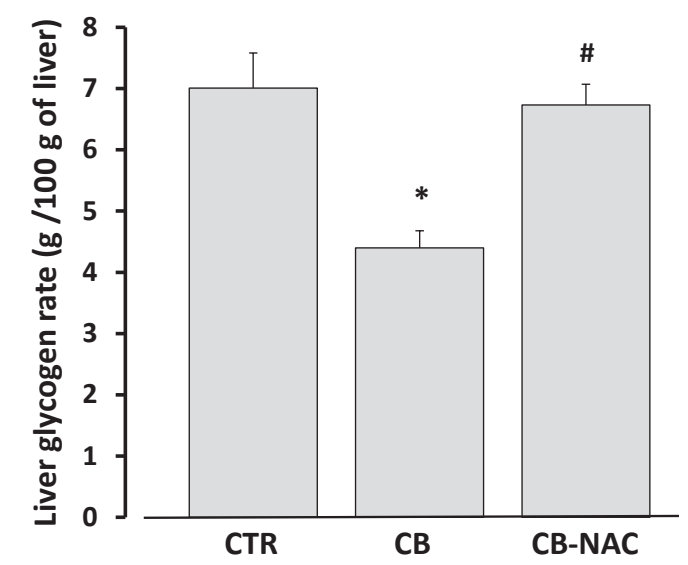

B

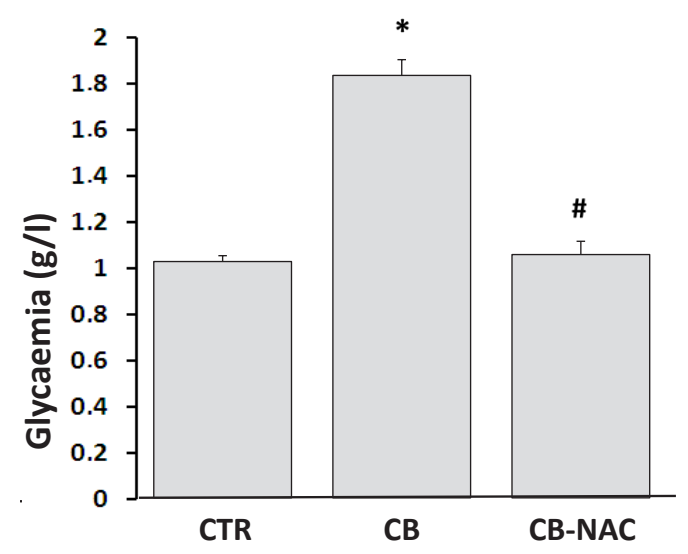

Figure 1. Effects of subchronic administration of carbosulfan/ $\mathrm{N}$-acetylcysteine on hepatic glycogen rate (A) and blood glucose level (B). Values are expressed as mean $\pm \mathrm{SD}(n=12){ }^{*} p<0.05$, significantly different from the control group; ${ }^{*} p<0.05$, significantly different from the CB group. CTR, control group; CB, carbosulfan-treated group; CB-NAC, NAC and carbosulfan-treated group. 
Table 2. Effects of carbosulfan and NAC treatment on the liver function tests of Wistar rats

\begin{tabular}{lrcc}
\hline & \multicolumn{1}{c}{ CTR } & CB & CB-NAC \\
\hline AST (U/l) & $85.7 \pm 6.43$ & $92.5 \pm 5.44$ & $89.239 \pm 4.349$ \\
ALT (U/l) & $40.9 \pm 5.96$ & $56.5 \pm 5.73^{*}$ & $50.895 \pm 2.94^{\star}$ \\
LDH (U/l) & $1014.3 \pm 58.8$ & $1149.49 \pm 117.2$ & $1144.47 \pm 83.876$ \\
ALP (U/l) & $222.41 \pm 15.6$ & $264.802 \pm 19.864^{*}$ & $233.368 \pm 29.216$ \\
ACP (U/l) & $11.06 \pm 0.57$ & $7.001 \pm 0.53^{*}$ & $8.658 \pm 1.198^{\star}$,\# \\
GGT(U/l) & $9.49 \pm 1.34$ & $17.037 \pm 1.742^{*}$ & $12.58 \pm 1.079^{\#}$ \\
\hline
\end{tabular}

AST, aspartate aminotransferase; ALT, alanine aminotransferase; LDH, lactate dehydrogenase; ALP, alkaline phosphatase; ACP, acide phosphatase; GGT, glutamyltransferase; CTR, control group; CB, carbosulfan-treated group; CB-NAC, animals received carbosulfan and NAC; NAC, N-acetylcysteine. Values are expressed as mean \pm SD $(n=12){ }^{*}$ significantly different from the control group $(p<0.05)$; \# significantly different from the CB group $(p<0.05)$.

NAC affect significantly lipid status. Indeed, supplementation for 30 days of NAC normalized the level of TG while they changed in CB-NAC group compared with CB group as shown in Figure 2. On the contrary, total cholesterol was not affected by NAC adding.

\section{Liver and kidney dysfunction}

The data demonstrating the level of liver and kidneys damage sustained following exposure to carbosulfan were shown in Tables 2, 3 and 4 . In order to determine whether the carbosulfan dosing $(25 \mathrm{mg} / \mathrm{kg})$ produced toxicity to animals, we measured plasma AST, ALT, LDH, ALP and GGT activities. Table 2 shows that carbosulfan increased the activity of those enzymes ALT, ALP, and GGT in plasma. This evidence suggests that this carbosulfan dose is able to induce some degree of liver toxicity. Also, carbosulfan caused a significant decrease in the albumin level. Longterm NAC treatment, which did not affect plasma ALT and PAL activity, was able to reverse carbosulfan-induced increase in plasma GGT activity. As shown in Table 3, significant increases in total protein and globulin concentrations were observed in serum of carbosulfan-treated rats and a significant decrease in albumin level, in comparison with the results of control animals. Moreover, supplementation of NAC on CB group reversed total protein and globulin levels to within the normal limits. On the other hand, NAC produced a slight reduction in carbosulfaninduced albumine release, but it was marginally significant $(p=0.075)$.

Carbosulfan-treatment caused a significant increase in urea concentration in the plasma of male rats (Table 4). Supplementation of NAC to carbosulfan-treated female rats normalized the levels of urea. The concentration of creatinine was significantly elevated in the carbosulfantreated group compared to the control. Also, there was a significant change in the concentration of creatinine in the NAC plus carbosulfan-treated rats, while the increase was still significantly higher in the carbosulfan-treated male rats (Table 4).
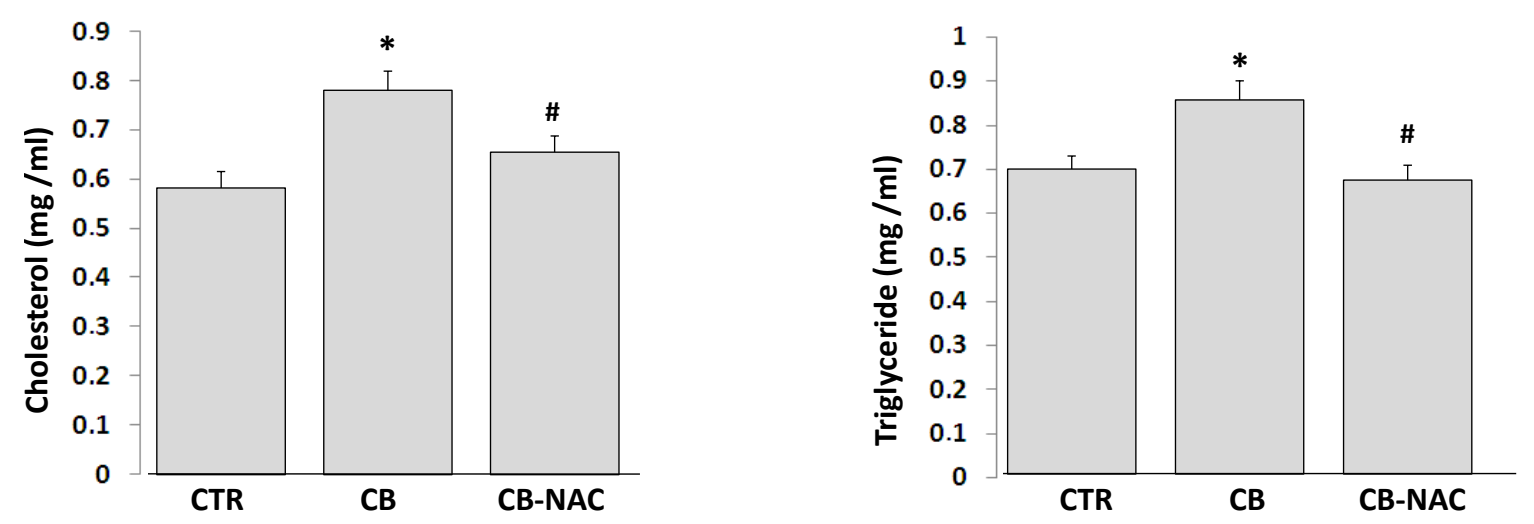

Figure 2. Effects of subchronic administration of carbosulfan/ $\mathrm{N}$-acetylcysteine on blood cholesterol and triglyceride level. Values are expressed as mean $\pm \mathrm{SD}(n=12){ }^{*} p<0.05$, significantly different from the control group; ${ }^{\#} p<0.05$, significantly different from the $\mathrm{CB}$ group. CTR, control group; CB, carbosulfan-treated group; CB-NAC, NAC and carbosulfan-treated group. 
Table 3. Effects of carbosulfan and NAC treatment on the hepatic protein of Wistar rats

\begin{tabular}{lccc}
\hline & CTR & CB & CB-NAC \\
\hline Serum total protein $(\mathrm{g} / \mathrm{dl})$ & $71.886 \pm 0.945$ & $87.318 \pm 0.62^{\star}$ & $70.861 \pm 1.09^{\#}$ \\
Albumine $(\mathrm{g} / \mathrm{dl})$ & $47.108 \pm 1.247$ & $30.915 \pm 1.954^{*}$ & $47.888 \pm 0.511^{\#}$ \\
Globuline $(\mathrm{g} / \mathrm{dl})$ & $21.977 \pm 1.501$ & $41.21 \pm 1.33^{*}$ & $25.258 \pm 0.847^{\#}$ \\
\hline
\end{tabular}

CTR, control group; CB, carbosulfan-treated group; CB-NAC, animals received carbosulfan and NAC. Values are expressed as mean \pm SD $(n=12) ;{ }^{*}$ significantly different from the control group $(p<0.05) ;{ }^{\#}$ significantly different from the CB group $(p<0.05)$.

\section{Oxidative stress}

The liver and kidney lipid peroxidation level of carbosulfantreated rats vary significantly during 30 days of experiment (Table 5).The lipid peroxidation level was higher in the liver and the kidney of treated group which had received carbosulfan. The supplementation of NAC in rats brought down the hepatic and real lipid peroxidation to the level comparable to rats of control group. Conversely, as depicted in Table 5, the levels of GSH and T-SH in rat treated with carbosulfan for 30 days significantly decreased in liver by 26.55 and $24.17 \%$ and in kidney by 49.01 and 35\%, respectively comparative to the control. A significant carbosulfan-NAC interaction for tissue GSH and T-SH levels was observed. Results demonstrate an increase in GSH and T-SH by 125 and $123.4 \%$ in liver. The decrease in renal GSH levels induced by carbosulfan was abolished by NAC administration (145.03\%).

Carbosulfan treatment caused a significant inhibition in both liver and kidney butyrylcholinesterase (BChE) activity (Table 5). NAC affect BChE activity per se neither reverse carbosulfan induced BChE decrease. Moreover, carbosulfan caused a significant increase in the activity of hepatic antioxidant enzymes SOD and CAT, besides renal SOD activity decreased. Supplementation of animals with a NAC ( $2 \mathrm{~g} / \mathrm{l}$ in drinking water) for 30 days caused a complete blockade of the carbosulfan-induced decrease in antioxidant enzymes activity in the liver and the kidney.

\section{Change in leukocyte level}

Carbosulfan significantly increased the white blood cells (WBC) counts $(28.42 \%)$ compared to the control group (Figure 3). Interestingly, NAC administration resulted in a significant reduction in WBC counts (17.51\%) as compared to carbosulfan-treated group.

\section{Discussion}

It has been previously reported that NAC is able to protect against carbosulfan-induced increases in oxidative markers of rat spleen (El-Bini Dhouib et al. 2014). In line with these reports, the present study demonstrates the beneficial effect of a subchronic NAC treatment (2 g/l in drinking water) against carbosulfan-induced impairment in the rat liver and kidney antioxidant defenses. In a previous study, we showed that in vivo subchronic treatment with NAC protects the spleen against the carbosulfan-toxicity and recovers from oxidative stress induced by carbosulfan (El-Bini Dhouib et al. 2014). In the present study, we demonstrated that oral NAC administration leads to a reversion of carbamate effects by preventing carbosulfan-induced decreases in antioxidant defenses and heptorenal damage. Since carbamate intoxication represents an important human health problem (Gupta 1994) and one of the major targets for carbamate toxicity is the liver that besides metabolic disorders there are evidences of oxidative stress. Our study constitutes an important contribution regarding a preventive treatment against the carbosulfan-induced impairment in antioxidant defense enzymes.

In toxicological studies, body and organ weights are important criteria for the evaluation of toxicity. In the present study, the final body weight of carbosulfan-treated rats was significantly $(p<0.05)$ lower than that of the control group. This may be attributed to a decreased food intake (anorexia or food avoidance), poor food palatability or increased

Table 4. Effects of carbosulfan and NAC treatment on the kidney function tests of Wistar rats

\begin{tabular}{lccc}
\hline & CTR & CB & CB-NAC \\
\hline Urea (mg/l) & $5.18 \pm 0.01$ & $6.55 \pm 0.03^{*}$ & $5.2 \pm 0.02^{\#}$ \\
Creatinine (mg/l) & $0.946 \pm 0.04$ & $4.13 \pm 0.16^{*}$ & $2.314 \pm 0.145^{\#}$ \\
Uric Acid (mg/l) & $4.968 \pm 0.09$ & $5.461 \pm 0.07$ & $4.997 \pm 0.66$ \\
\hline
\end{tabular}

CTR, control group; CB, carbosulfan-treated group; CB-NAC, animals received carbosulfan and NAC. Values are expressed as mean \pm SD $(n=12) ;{ }^{*}$ significantly different from the control group $(p<0.05) ;{ }^{\#}$ significantly different from the CB group $(p<0.05)$. 
Table 5. Effects of carbosulfan and NAC treatment on liver and kidney oxidative stress of Wistar rats

\begin{tabular}{|c|c|c|c|}
\hline & CTR & $\mathrm{CB}$ & CB-NAC \\
\hline \multicolumn{4}{|l|}{ Liver } \\
\hline MDA (nmol/mg protein) & $0.253 \pm 0.07$ & $0.395 \pm 0.045^{\star}$ & $0.263 \pm 0.022^{\#}$ \\
\hline GSH ( $\mu \mathrm{mol} / \mathrm{mg}$ protein $)$ & $8.85 \pm 0.44$ & $6.5 \pm 0.14^{*}$ & $8.758 \pm 0.431^{\#}$ \\
\hline $\mathrm{T}-\mathrm{SH}(\mathrm{mM})$ & $0.426 \pm 0.029$ & $0.323 \pm 0.018^{*}$ & $0.422 \pm 0.026^{\#}$ \\
\hline $\mathrm{BChE}(\mathrm{nmol} / \mathrm{min} / \mathrm{mg}$ protein $)$ & $7.85 \pm 0.6$ & $4.88 \pm 0.591^{*}$ & $6.321 \pm 0.21^{\#}$ \\
\hline SOD (U/mg protein) & $23.694 \pm 1.425$ & $40.58 \pm 5.166^{*}$ & $26.989 \pm 0.689^{\#}$ \\
\hline CAT (U/mg protein) & $3.671 \pm 0.542$ & $8.313 \pm 0.304^{*}$ & $5.043 \pm 0.704^{\#}$ \\
\hline \multicolumn{4}{|l|}{ Kidney } \\
\hline MDA (nmol/mg protein) & $1.379 \pm 0.163$ & $1.758 \pm 0.209^{\star}$ & $1.365 \pm 0.212^{\#}$ \\
\hline GSH ( $\mu \mathrm{mol} / \mathrm{mg}$ protein) & $6.457 \pm 2.3$ & $3.292 \pm 1.12^{*}$ & $5.989 \pm 2.005^{\#}$ \\
\hline $\mathrm{T}-\mathrm{SH}(\mathrm{mM})$ & $0.06 \pm 0.006$ & $0.039 \pm 0.001^{\star}$ & $0.051 \pm 0.002$ \\
\hline $\mathrm{BchE}$ (nmol/min/mg protein) & $6.347 \pm 0.255$ & $4.064 \pm 0.429^{\star}$ & $6.216 \pm 0.24^{\#}$ \\
\hline $\mathrm{SOD}(\mathrm{U} / \mathrm{mg}$ protein $)$ & $15.520 \pm 3.24$ & $6.028 \pm 1.971^{\star}$ & $9.587 \pm 0.839^{\star, \#}$ \\
\hline CAT (U/mg protein) & $0.323 \pm 0.018$ & $0.326 \pm 0.029$ & $0.378 \pm 0.026$ \\
\hline
\end{tabular}

CTR, control group; CB, carbosulfan-treated group; CB-NAC, animals received carbosulfan and NAC. Values are expressed as mean \pm SD $(n=12) ;{ }^{*}$ significantly different from the control group $(p<0.05) ;{ }^{\#}$ significantly different from the CB group $(p<0.05)$.

degradation of lipids and protein due to treatment-related toxicity (Mansour and Mossa 2010). Also, weight loss observed in the carbosulfan treatment group may be a result of the combination of oxidative stress and adrenal-mediated stress caused by the inhibition of cholesterol ester hydrolase. Carbosulfan is known to show its toxic effects by inhibiting cholinesterase activity which could be due to the less food consumption and/or fluid and electrolyte loss (Yi et al. 2006; El-Bini Dhouib et al. 2014). This data is in consonance with those obtained with organophosphorous pesticides by Ambali et al. (2007) and Al-Othman et al. (2012). Results showed that there is a significant increase in the relative liver and kidney weight in rats exposed to carbosulfan compared with

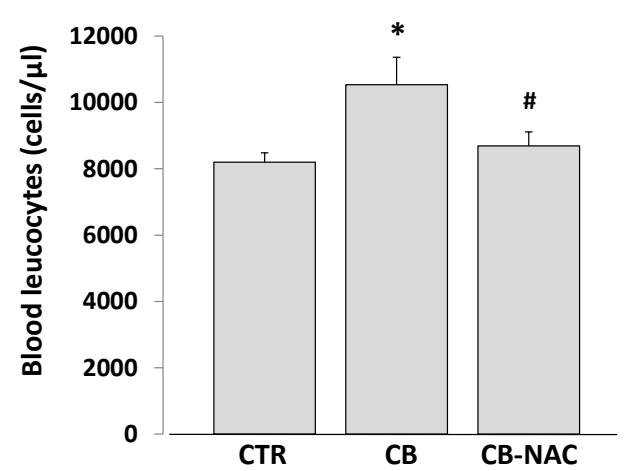

Figure 3. Effects of subchronic administration of carbosulfan/Nacetylcysteine on blood leucocytes level. Values are expressed as mean $\pm \mathrm{SD}(n=12) ;{ }^{*} p<0.05$, significantly different from the control group; ${ }^{\#} p<0.05$, significantly different from the $\mathrm{CB}$ group. CTR, control group; CB, carbosulfan-treated group; CB-NAC, animals received carbosulfan and NAC. control rats (Table 1). The increase in relative organ weight in rats exposed to carbamates pesticides seems to be due to toxic potential of pesticide, and it is in agreement with Al-Sarat et al. (2011) in rabbits, Institoris et al. (2002) in rats.

Curiously, the energy intake was significantly similar in the two groups, CB and CB-NAC (Table 1), while enhanced food and water intake were only observed in $\mathrm{CB}$ group. This observation suggested that dietary factors other than energy intake play important role in body weight regulation. Note that the final body weight and the mass gain was lowest in $\mathrm{CB}$ group, and that NAC normalized those parameters in CB-NAC group (Table 1) indicating that one mechanism by which NAC ameliorate the body weight gain was by modified energy expenditure. In the other hand, NAC attenuated the increases in liver and kidney weight changes caused by carbosulfan. $\mathrm{N}$-acetylcysteine is known for its chelation potential and supplementation of NAC during pesticide intoxication reduced the levels of carbosulfan in the liver and the kidney. In consistent with our results, studies of De Flora et al. (1986) reported that NAC lowered the levels of ethyl carbamate in tissues of mice.

In the present study, carbosulfan treatment produced significant increase in plasma glucose levels. This rise in glycaemia was along with reduction in body weight shown in Table 1. NAC treatment significantly reduced the plasma glucose levels as compared with carbosulfan-treated group. The partial lowering of glucose levels by NAC might be attributable to its effect in preventing hyperglycemia-induced insulin resistance (Haber et al. 2003); since NAC has been seen not to increase plasma insulin levels in the diabetic rats (Xia et al. 2007). In addition, NAC might lower glucose levels by its antioxidant action as various antioxidants have been 
shown to partially lower plasma glucose levels (Franzini et al. 2008). According to our results, carbosulfan stimulates glycogenolysis pathway. Thus, treated rats show a lower level of liver glycogen. Similar results have been reported in rats after oral administration of diazinon (Teimouri et al. 2006) and acephate (Joshi and Rajini 2009). Hepatic glucose utilization requires glucokinase activity which plays a crucial role in the homeostasis of glucose and glycogen metabolism (Pilkis and Granner 1992). Additionally, NAC supplementation affects hepatic glycogen level after carbosulfan exposure. To the best of our knowledge, this is the first study showing the effects of chronic antioxidant therapy, with NAC on the hepatic glycogen level changes induced by carbamates pesticides.

The carbosulfan dose used in the present study caused a risein plasma ALP and GGT activity. In parallel, it was possible to observe an increase in ALT activity, which was marker of hepatic toxicity. Altogether, these data point to a significant level of systemic toxicity for the carbosulfan dosage used. Regarding ACP and ALP activities in rat blood, it is clear that treatment with carbosulfan significantly decreased ACP activity, while increased ALP as compared to controls. Also, Igwenyi et al. (2014) reported a significant increase in ALP activity, in serum and liver of experimental animals treated with Baygon (pesticide brand). The decrease in ACP may be related either to leakage of the enzyme into extracellular compartments or to tissue damage (Ambali et al. 2007). ACP was used as a marker for lysosomal functions in liver cells in order to estimate the interference with catabolic and autophagic processes in the liver. Also, the change in the ACP activity may be related to the biotransformation and elimination of the tested pesticide (Khan 2014). The significant elevation in the activity of ALP indicated damage to any or all of the organs producing this enzyme such as the liver and kidney is due to leakage of lysosomal enzymes into the cytoplasm and renal necrosis and pyknotic nuclei. This result is paralleled by the result of Ambali et al. (2007) and Rahman et al. (2000) suggested that the alteration in the activities of ALP and ACP in different tissues might be due to the increased permeability of plasma membrane or cellular necrosis, showing the stress condition of the treated animals. In addition, the alteration in these enzymes may be due to liver dysfunction and disturbance in the biosynthesis of these enzymes with change in the permeability of liver membrane takes place. Moreover, carbosulfan is mainly due to the leakage of these enzymes from the liver cytosol into the blood stream. In the other hand, $\mathrm{N}$-acetylcysteine treatment was unable to completely reverse carbosulfan-induced ALT and ALP increase; however, it caused some degree of hepatic protection by recovering plasma ACP and GGT activity, as shown in Table 2.

In this study, the level of total protein and globulin was significantly increased on carbosulfan-treated animals.
Moreover, albumin level decreased in carbosulfan-treated group. Also, several studies have shown that albumin production by liver can be decreased under pesticide exposure (Yousef et al. 2003; Kalender et al. 2010). The albumin level may decrease in individuals that liver function disorders after carbosulfan treatment. Albumin most often transports or binds drugs or chemicals (Kalender et al. 2010). Some insecticides increase the total cholesterol and triglyceride levels (Kalender et al. 2010). The changes of total protein level is based on function of albumin and globulin proportion, that could vary based on immunocompetence "status" of the animals or other physiopathological condition (Petterino and Argentino-Storino 2006). Thus, increased serum cholesterol and triglyceride levels can be attributed to the effects of the pesticide on the permeability of liver cell membranes (Yousef et al. 2003). Also, increase in serum cholesterol and GGT after subchronic carbosulfan exposure directly indicates the hepatorenal injury. The formation of fatty lipid steatosis after carbosulfan administration is mainly due to accumulation of triglycerides. The reason for the altered activities of marker enzymes during the toxicity might be due to the fact that oxidative damage in a cell or tissue occurs when the concentration of reactive oxygen species $\left(\mathrm{O}_{2}, \mathrm{H}_{2} \mathrm{O}_{2}\right.$, and $\mathrm{OH}$ ) exceeds beyond the antioxidant capability of the cell (Demiryilmaz et al. 2012). Ksheerasagar and Kaliwal (2010) have also observed similar type of results in rat serum when treated with carbosulfan on liver and kidney of mice. A significant reduction in liver function markers toward respective control values by NAC is an indication of the stabilization of the plasma membranes of the hepatic tissue caused by carbosulfan.

Our results also revealed that NAC ameliorated the kidney damage induced by carbosulfan treatment. The alterations in urea and creatinine concentrations are an indication of kidney damage. Elevated creatinine usually indicates glomerular damage which may be due to increased protein catabolism and the conversion of ammonia to urea as a result of increased synthesis of arginase enzyme involved in urea production (Harper et al. 1979). Kaur et al. (2012) also observed kidney damage in carbofuran toxicity. Treatment with the NAC reduced the level of above-mentioned markers in serum caused by carbosulfan intoxication in rats. This indicates that NAC tend to prevent kidney damage by maintaining in the integrity of cell membrane, thereby suppress the leakage of enzymes through membranes, exhibiting hepatorenal protective activity.

Functional alteration mechanism in the liver and kidneys can be due to the presence of an inflammatory condition or oxidative stress. In fact, in the present study, carbosulfantreated rats also exhibited significantly increases WBC counts. This increase in WBC may indicate an activation of the animal's defense mechanisms and immune system. 
It could be related to the liver damage and result from an inflammation caused by carbosulfan hepatotoxicity (Kandil et al. 2006). These changes and mechanisms also related to increase of ALP, and ALT activities in serum. Because their levels in serum show that cellular degeneration or destruction occurs in liver (Elhalwagy et al. 2008). Interestingly, NAC treatment caused a significant decrease in total WBC values. Our results corroborate with those of De la Fuento and Hernanz (2012), they showed that NAC in vitro improves the number and the functions of leucocytes in old mice.

A central mechanism of hepatic injury during carbosulfan exposure is the development of oxidative stress due to generation of reactive oxygen species. In the current study, carbosulfan toxicity was evidenced by determination of liver and kidney function tests, markers of oxidative stress by estimation of LPO level, GSH and T-SH content, SOD and catalase enzymes activities. Free radicals are molecules such as superoxide anion, hydroxyl radical, nitric oxide and lipid radicals. In reactions between free radicals and polyunsaturated fatty acids may result in a fatty acid peroxyl radical ( $\left.\mathrm{R}-\mathrm{COO}{ }^{\circ}\right)$ that can attack fatty acid side chains and initiate production of other lipid radicals. End products of lipid peroxidation have cytotoxic and mutagenic properties. Cells under oxidative stress display various dysfunctions due to damages caused by reactive oxygen species to lipids, proteins and DNA. Oxidative stress in cells can be partially responsible for the toxic effects of carbamates pesticides. Carbosulfan induces spleen toxicity in part by increasing of free radical production (El-Bini Dhouib et al. 2014). Lipid peroxidation is known to be one of the molecular mechanisms for cell injury in pesticide poisoning and is associated with a decrease in cellular antioxidants such as superoxide dismutase and catalase (Kaur and Sandhir 2006; Lasram et al. 2014a). Hepatic catalase activity was found to be increased in this study. This enzyme is responsible for balancing the production of $\mathrm{H}_{2} \mathrm{O}_{2}$ and superoxide radicals. As CAT activity increases in the present study due to excessive production hydroxyl ions. The alteration in tissue SOD activity further indicated an increased superoxide radical formation. Enhanced levels of hydroxyl radical also initiate MDA levels to rise in the liver and kidney regions. Similar reports have shown an elevation in the status of LPO in liver and kidney during carbofuran (Kaur and Sandhir 2006) and carbaryl exposure (El-Demerdash et al. 2013) and our results are in accordance with these reports.

In the literature, carbosulfan is a direct cholinesterase inhibitor and is converted to its toxic form by cytochrome P450 mediated reactions (Abass et al. 2009). We previously demonstrated that spleen $\mathrm{BChE}$ was significantly depressed by $25 \mathrm{mg} / \mathrm{kg}$ carbosulfan exposure (El-Bini Dhouib et al. 2014). In the present study, we demonstrated that carbosulfan caused a significant BChE inhibition in the liver and kidney. Many authors reported that carbamate insecticides act by binding to $\mathrm{BChE}$ leading to its inhibition. The authors also suggested that the increase in free radical and lipid peroxidation levels can be the result of $\mathrm{BChE}$ decreasing activity, since $\mathrm{BChE}$ is involved in detoxification mechanism. Our study demonstrated that in the liver and kidney of rat $\mathrm{BChE}$ activities were at similar levels. BChE specific activity was inhibited by NAC exposure in a dose-dependent manner. Reason(s) of this mechanism is (are) uncertain and further investigations are needed to explain the inhibitory effect of NAC on BChE specific activity.

In the present study, we have observed that the depletion of the levels of non-enzymic antioxidants such as GSH due to the excessive organ damage and oxidative stress is caused by carbosulfan toxicity. It plays a central role in the antioxidant defense system, metabolism and detoxification of exogenous and endogenous substances (Eraslan et al. 2009). Also, GSH with its -SH group functions as a catalyst for disulfide exchange reactions, and contributes in $\mathrm{H}_{2} \mathrm{O}_{2}$ detoxification. Thiols, together with non-enzymatic and enzymatic factors, regulate the intracellular metabolism defending biological structures and functions from the noxious attack by ROS (Di Simplicio et al. 1998). Moreover, depletion of T-SH was also evidenced suggesting that the non-protein sulfhydryl compounds and protein-bound sulfhydryl groups could alter each other through thiol/ disulfide exchange. Carbamate pesticide has high affinity for endogenous thiol molecules as GSH and toxicity of carbosulfan causes irreversible binding with up to two GSH tripeptides (El-Demerdash et al. 2013). The conjugation of carbosulfan with GSH molecule process is desirable in that it results in the excretion of the toxic metabolite like carbofuran in to bile. In the present investigation, it was observed that carbosulfan intoxication significantly depletes the GSH content in liver and kidney and thus reducing the antioxidant potential and accelerating the lipid peroxidation, resulting hepatorenal damage. The kidneys are the primary target organ for accumulation and toxicity of carbosulfan. In fact, Maroni et al. (2000) found minors metabolites: carbofuran and 3-ceto-carbofuran in the kidney. Treatments with NAC attenuated the carbosulfan -induced oxidative damage. In fact, treatment with NAC restored the increased MDA and reduced GSH levels to the normal values in hepatic and kidney tissue. This could be attributed to the excellent properties of NAC. This property seems to be due to its ability to scavenge free radicals. It is reported that antioxidant may enhance the property of chelating agent as evidenced by our group against other form of carbosulfan which is dangerous as pesticide toxicity. $\mathrm{N}$-acetylcysteine (NAC) acts directly as free radical scavenger and precursor of reduced glutathione and glutathione peroxidase enzyme (Cotgreave 1997). The present study demonstrates the therapeutic role of NAC and it may be 


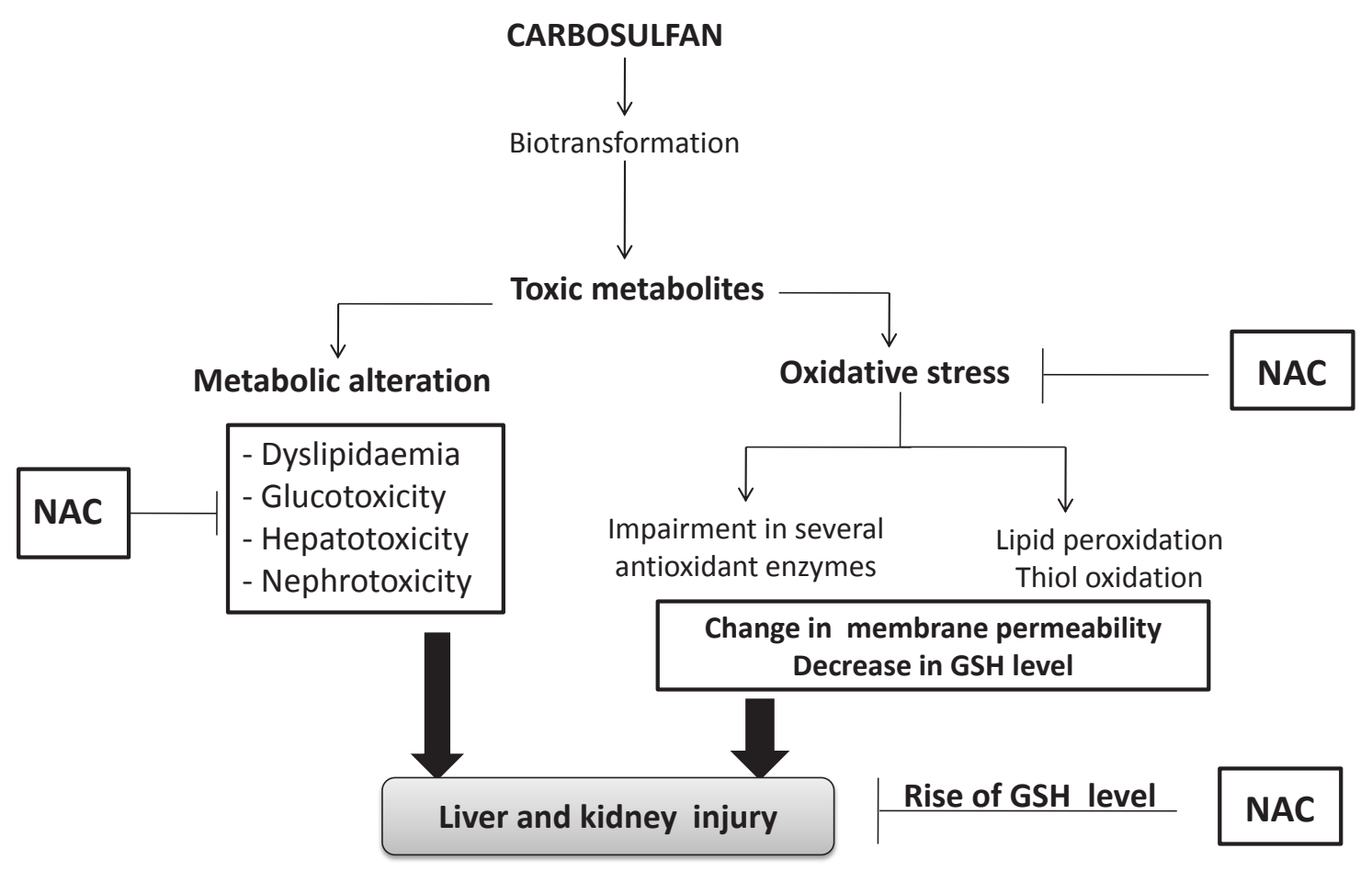

Figure 4. Protective effect of N-acetylcysteine (NAC) against cell damage induced by carbosulfan in rats liver and kidney cells. Carbosulfan acts directly on hepatocytes and nephrocytes to induce liver and kidney injury and oxidative stress. Tissues damages sensitize hepatic and renal cells to release enzymes in the blood. NAC treatment also augments intracellular GSH concentration, which redox-modulates liver and kidney function.

an ideal therapeutic agent in therapy for use in subchronic carbosulfan toxicity (Figure 4). N-acetylcysteine has antioxidant role and it reacts most strongly with hydroxyl radical and with hypochloric acid, but reacts poorly with the hydrogen peroxide and superoxide radicals (Arakawa and Ito 2007). It may also exert an indirect antioxidant effect by facilitating GSH biosynthesis and supplying GSH for GSH-Px-catalyzed reactions (Saricaoglu et al. 2005). GSH-Px converts hydrogen peroxide to water (Halliwell 2006). However, liver GSH levels in the current study were increased by NAC administration because of facilitating GSH biosynthesis. Number of researchers suggested that NAC is effective as a chelating agent in reducing the toxicity of pesticide when it administrated on intoxicated animals (Borgstrom et al. 1986; Zimet 1988; Lasram et al. 2014b).

\section{Conclusions}

In conclusion, our results indicate that $\mathrm{N}$-acetylcysteine was able to recover carbosulfan-induced impairment in several antioxidant enzymes, showing to be a potential agent to be used against the pro-oxidative effects of carbamates compounds such as carbosulfan. In addition, the data showed that NAC attenuates the pathogenesis of the liver and kidney cell injury induced by carbosulfan. There is evidence that the stabilization of free radicals play a crucial role in the protective mechanisms of NAC against carbosulfan toxicity. The interactions between carbosulfan and NAC are still obscure although evidences of molecular mechanism and need more in vivo and in vitro investigations since not available in the literature.

\section{References}

Abass K., Reponen P., Mattila S., Pelkonen O. (2009): Metabolism of carbosulfan I. Species differences in the in vitro biotransformation by mammalian hepatic microsomes including human. Chem. Biol. Interact. 181, 210-219 http://dx.doi.org/10.1016/j.cbi.2009.06.001

Aebi H. (1984): Catalase in vitro. Methods in Enzymology (3rd ed.). pp. 121-126, vol. 105, Lippincott-Raven Publishers, Philadelphia

Al-Othman A. M., Al-Othman Z. A., El-Desoky G. B., Yusuf K., Aboul-Soud M. A. M. (2012): Ameliorative effect of atocopherol and selenium on effects of malathion on plasmatic biochemical indices and lesions in the liver of rats. Curr. Pharm. Anal. 8, 214-218 
http://dx.doi.org/10.2174/1573412911208020214

Al-Sarat A. S., Hafiz A. M., Bayoumi A. E., Hussein H. I., AboBaer Y. (2011): Impact of fenitrothion thermal fogging on some biological and parameters in New Zealand rabbits as non-target organisms. Int. J. Agric. Biol. 13, 435-438

Ambali S., Akanbi D., Igbokwe N., Shittu M., Kawu M., Ayo J. (2007): Evaluation of sub chronic chlorpyrifos poisoning on hematological and serum biochemical changes in mice and protective effect of vitamin C. J. Toxicol. Sci. 32, 111-120 http://dx.doi.org/10.2131/jts.32.111

Arakawa M., Ito Y. (2007): N-acetylcysteine and neurodegenerative diseases: basic and clinical pharmacology. Cerebellum 19, $1-7$ http://dx.doi.org/10.1080/14734220601142878

Barham D., Trinder P. (1972): An improved colour reagent for the determination of blood glucose by the oxidase system. Analyst. 97, 142-145 http://dx.doi.org/10.1039/an9729700142

Bartels H., Bohmer M., Heierli C. (1972): Serum creatinine determination without protein precipitation. Clin. Chim. Acta 37, 193-197 http://dx.doi.org/10.1016/0009-8981(72)90432-9

Begue J. A. Aust S. D. (1978): Microsomal lipid peroxidation. Methods Enzymol. 52, 302-310 http://dx.doi.org/10.1016/S0076-6879(78)52032-6

Binukumar B. K., Bal A., Kandimalla R., Sunkaria A., Gill K. D. (2010): Mitochondrial energy metabolism impairment and liver dysfunction following chronic exposure to dichlorvos. Toxicol. 270, 77-84 http://dx.doi.org/10.1016/j.tox.2010.01.017

Borgstrom L., Kagedal B., Paulsen O. (1986): Pharmacokinetics of $\mathrm{N}$-acetylcysteine in man. Eur. J. Clin. Pharmacol. 31, $217-222$ http://dx.doi.org/10.1007/BF00606662

Bradford M. M. (1976): A rapid and sensitive method for the quantitation of microgram quantities of protein utilizing the principal of protein-dye binding. Anal. Biochem. 72, 248-254 http://dx.doi.org/10.1016/0003-2697(76)90527-3

Buege J. A., Aust S. D. (1976): Microsomal lipid peroxidation. Method. Enzymol. 52, 302-310 http://dx.doi.org/10.1016/S0076-6879(78)52032-6

Celik I., Yilmaz Z., Turkoglu V. (2009): Hematotoxic and hepatotoxic effects of dichlorvos at sublethal dosages in rats. Environ. Toxicol. 24, 128-132 http://dx.doi.org/10.1002/tox.20390

Cotgreave I. A. (1997): N-acetylcysteine: pharmacological considerations and experimental and clinical applications. Adv. Pharmacol. 38, 205-227 http://dx.doi.org/10.1016/S1054-3589(08)60985-0

De Flora S., Astengo M., Serra D., Bennicelli C. (1986): Inhibition of urethan-induced lung tumors in mice by dietary $\mathrm{N}$-acetylcysteine. Cancer Letters 32, 235-241 http://dx.doi.org/10.1016/0304-3835(86)90175-8

De la Fuente M., Hernanz A. (2012): The antioxidant N-acetylcysteine in vitro improves several functions of peritoneal leucocytes from old mice approaching their values to those of adult animals. J. Appl. Biomed. 10, 79-90 http://dx.doi.org/10.2478/v10136-012-0005-z de Silva H. J., Wijewickrema R., Senanayake N. (1992): Does pralidoxime affect outcome of management in acute organophosphorus poisoning? Lancet 339, 1136-1138 http://dx.doi.org/10.1016/0140-6736(92)90733-J

Demiryilmaz E., Sener N., Cetin D., Altuner B., Suleyman F., Albayrak et al. (2012): Biochemically and histopathologically comparative review of thiamine's and thiamine pyrophosphates oxidative stress effects generated with methotrexate in rat liver. Med. Sci. Monit. 18, 475-481 http://dx.doi.org/10.12659/MSM.883591

Di Simplicio P., Cacace M. G., Lusini L., Giannerini F., Giustarini D., Rossi R. (1998): Role of protein-SH groups in redox homeostasis - the erythrocyte as a model system. Arch. Biochem. Bioph. 355, 145-152 http://dx.doi.org/10.1006/abbi.1998.0694

Durak D., Uzun F. G., Kalender S., Ogutcu A., Uzunhisarcikli M., Kalender Y. (2009): Malathion-induced oxidative stress in human erythrocytes and the protective effect of vitamins $\mathrm{C}$ and E in vitro. Environ. Toxicol. 24, 235-242 http://dx.doi.org/10.1002/tox.20423

El Midaoui A., Ismael M.A., Lu H., de Champlain J., Couture R. (2008): Comparative effects of Nacetyl- L-cysteine and ramipril on arterial hypertension, insulin resistance, and oxidative stress in chronically glucose-fed rats. Can. J. Physiol. Pharmacol. 86, 752-760 http://dx.doi.org/10.1139/Y08-090

El-Bini Dhouib I., Lasram M. M., Abdeladhim M., Gharbi N., Ben Ahmed M., El-Fazaa S. (2014): Immunosuppression and oxidative stress induced by subchronic exposure to carbosulfan in rat spleen; Immunomodulatory and antioxidant role of $\mathrm{N}$ acetylcysteine. Toxicol. Mech. Methods 24, 417-427 http://dx.doi.org/10.3109/15376516.2014.928764

El-Demerdash F., Dewer Y., El Mazoudy R. H., Attia A. A. (2013): Kidney antioxidant status, biochemical parameters and histopathological changes induced by methomyl in CD-1 mice. Exp. Toxicol. Pathol. 65, 897-901 http://dx.doi.org/10.1016/j.etp.2013.01.002

Elhalwagy M. E. A., Darwish N. S., Zaher E. M. (2008): Prophylactic effect of green tea polyphenols against liver and kidney injury induced by fenitrothion insecticide. Pestic. Biochem. Phys. 91, 81-89 http://dx.doi.org/10.1016/j.pestbp.2008.01.006

Ellman G. L., Courtney K. D., Andres V. J., Featherstone R. M. (1961): A new and rapid colorimetric determination of acethylcholinesterase activity. Biochem. Phamacol. 7, 88-95 http://dx.doi.org/10.1016/0006-2952(61)90145-9

Eraslan G., Kanbur M., Silici S. (2009): Effect of carbaryl on some biochemical changes in rats: The ameliorative effect of bee pollen. Food Chem. Toxicol. 47, 86-91 http://dx.doi.org/10.1016/j.fct.2008.10.013

Fawcett J. K., Scott J. E. (1960): A rapid and precise method for the determination of urea. J. Clin. Pathol. 13, 156-159 http://dx.doi.org/10.1136/jcp.13.2.156

Franzini L., Ardigo D., Zavaroni I. (2008): Dietary antioxidants and glucose metabolism. Curr. Opin. Clin. Nutr. Metab. Care 11, 471-476 http://dx.doi.org/10.1097/MCO.0b013e328303be79

Good C. A., Krames H., Somogyi M. (1933): Chemical procedures for analysis of polysaccharides. Method Enzymol. 10, 34 
Grinberg L., Fibach E., Amer J., Atlas D. (2005): N-acetylcysteine amide, a novel cell-permeating thiol, restores cellular glutathione and protects human red blood cells from oxidative stress. Free Radic. Biol. Med. 38, 136-145 http://dx.doi.org/10.1016/j.freeradbiomed.2004.09.025

Gupta R. C. (1994): Carbofuran toxicity. J. Toxicol. Environ. Health 43, 383-418 http://dx.doi.org/10.1080/15287399409531931

Haber C. A., Lam T. K., Yu Z., Gupta N., Goh T., Bogdanovic E., Giacca A., Fantus I. G. (2003): N-acetylcysteine and taurine prevent hyperglycemia-induced insulin resistance in vivo: possible role of oxidative stress. Am. J. Physiol. Endocrinol. Metab. 285, 744-753

http://dx.doi.org/10.1152/ajpendo.00355.2002

Halliwell B. (2006): Oxidative stress and neurodegeneration: where are we now. J. Neurochem. 97, 1634-1658 http://dx.doi.org/10.1111/j.1471-4159.2006.03907.x

Harper H. A., Rodwell V. W., Mayes P. A. (1979): Review of Physiological Chemistry. Lange Medical Publications, Los Altos, CA, USA

Henry J. P., Massey J. B., Kusserow S. K., Gotto A. M. (1978): Kinetics of lipid-protein interactions: interaction of apolipoprotein A-I from human plasma high density lipoproteins with phosphatidylcholines. Biochemistry 17, 1183-1188 http://dx.doi.org/10.1021/bi00600a008

Hu M. L., Dillard C. J. (1994): Plasma SH and GSH measurement. Methods Enzymol. 233, 385-387

Igwenyi I. O., Aboh N., Nwachukwu N., Ibiam U. A., Offor C. E., Aja P. M., Agbafor K. N. (2014): Effect of baygon insecticide on the activities of total, alkaline and acid phosphatases of selected tissues of albino rats. J. Pharm. Biol. Sci. 9, 41-43

Institoris L., Siroki O., Undeger U., Basaran N., Desi I. (2002): Immunotoxicological investigation in rats dosed repeatedly with combinations of cypermethrin, $\mathrm{As}(\mathrm{III})$, and $\mathrm{Hg}(\mathrm{II})$. Toxicology 172, 59-67 http://dx.doi.org/10.1016/S0300-483X(01)00589-3

Joshi A. K., Rajini P. S. (2009): Reversible hyperglycemia in rats following acute exposure to acephate, an organophosphorus insecticide: role of gluconeogenesis. Toxicology 257, 40-45 http://dx.doi.org/10.1016/j.tox.2008.12.006

Kalender S., Uzun F. G., Durak D., Demir F., Kalender Y. (2010): Malathion-induced hepatotoxicity in rats: the effects of vitamins $\mathrm{C}$ and E. Food Chem. Toxicol. 48, 633-638 http://dx.doi.org/10.1016/j.fct.2009.11.044

Kamboj A., Kiran R., Sandhir R. (2006): N-acetylcysteine ameliorates carbofuran induced alterations in lipid composition and activity of membrane bound enzymes. Mol. Cell. Biochem. 286, $107-114$ http://dx.doi.org/10.1007/s11010-005-9100-8

Kandil M. A., El-Kashoury A. A., El-Said M. M., El-Herrawy M. A. (2006): Interactive effects of imidacloprid, profenofos and carbosulfan at low concentrations on homeostasis and haematological indices in male albino rats. J. Egypt. Soc. Toxicol. $35,69-78$

Kaur B., Khera A., Sandhir R. (2012): Attenuation of cellular antioxidant defense mechanisms in kidney of rats intoxicated with carbofuran. J. Biol. Mol. Toxicol. 26, 393-398 http://dx.doi.org/10.1002/jbt.21433
Kaur M., Sandhir R. (2006): Comparative effects of acute and chronic carbofuran exposure on oxidative stress and drug metabolizing enzymes in liver. Drug Chem. Toxicol. 29, 415-421 http://dx.doi.org/10.1080/01480540600837969

Khan S. (2014): Endosulphan concentration alters biomarkers in albino rat. Indian J. Pharm. Biol. Res. 2, 14-17

Khan S. M., Kour G. (2007): Sub-acute oral toxicity of chlorpyrifos and protective effect of green tea extract. Pest. Biochem. Physiol. 89, 118-123 http://dx.doi.org/10.1016/j.pestbp.2007.04.005

Ksheerasagar R. L., Kaliwal B. B. (2010): Effect of mancozeb on thyroid, testis, accessory reproductive organs and biochemical constituents in albino mice. J. Rec. Res. Sci. Technol. 2, 7-17

Lasram M. M., Bini Dhouib I., Bouzid K., Lamine A. J., Annabi A., Belhadjhmida N., Ahmed M. B., El Fazaa S., Abdelmoula J., Gharbi N. (2014a): Association of inflammatory response and oxidative injury in the pathogenesis of liver steatosis and insulin resistance following subchronic exposure to malathion in rats. Environ. Toxicol. Pharmacol. 38, 542-553 http://dx.doi.org/10.1016/j.etap.2014.08.007

Lasram M. M., Bini Douib I., Bouzid K., Annabi A., El Elj N., Dhouib H., El Fazaa S., Abdelmoula J., Gharbi N. (2014b): Effects of N-acetyl-L-cysteine, in vivo, against pathological changes induced by malathion. Toxicol. Mech. Methods 24, 294-306 http://dx.doi.org/10.3109/15376516.2014.886003

Lasram M. M., Annabi A. B., El Elj N., Selmi S., Kamoun A., El Fazaa S., Gharbi N. (2009): Metabolic disorders of acute exposure to malathion in adult Wistar rats. J. Hazard. Mater. 163, 1052-1055 http://dx.doi.org/10.1016/j.jhazmat.2008.07.059

Lott J. A., Turner K. (1975): Evaluation of Trinder's glucose oxidase method for measuring glucose in serum and urine. Clin. Chem. 21, 1754-1760

Lowry O. H., Rosebrough N. J., Farr A. L., Randall R. J. (1951): Protein measurement with the Folin phenol reagent. J. Biol. Chem. 193, 265-275

Mansour S. A., Mossa A. T. H. (2010): Oxidative damage, biochemical and histopathological alterations in rats exposed to chlorpyrifos and the antioxidant role of zinc. Pest. Biochem. Physiol. 96, 4-23 http://dx.doi.org/10.1016/j.pestbp.2009.08.008

Maroni M., Colosio C., Ferioli A., Fait A. (2000): Carbamate pesticides. Toxicology 143, 9-37

Misra H. P., Fridovich I. (1972): The role of superoxide anion in the autoxidation of epinephrine and a simple assay for superoxide dismutase. J. Biol. Chem. 247, 3170-3175

Ortolani O., Conti A., De Gaudio A. R., Moraldi E., Cantini Q., Novelli G. (2000): The effect of glutathione and $\mathrm{N}$-acetylcysteine on lipoperoxidative damage in patients with early septic shock. Am. J. Respir. Crit. Care Med. 161, 1907-1911 http://dx.doi.org/10.1164/ajrccm.161.6.9903043

Petterino C., Argentino-Storino A. (2006): Clinical chemistry and haematology historical data in control Sprague-Dawley rats from pre-clinical toxicity studies. Exp. Toxicol. Pathol. 57, 213-219 
http://dx.doi.org/10.1016/j.etp.2005.10.002

Pilkis S. J., Granner D. K. (1992): Molecular physiology of the regulation of hepatic gluconeogenesis and glycolysis. Annu. Rev. Physiol. 54, 885-909 http://dx.doi.org/10.1146/annurev.ph.54.030192.004321

Raheja G., Gill K. D. (2007): Altered cholinergic metabolism and muscarinic receptor linked second messenger pathways after chronic exposure to dichlorvos in rat brain. Toxicol. Ind. Health 23, 25-37 http://dx.doi.org/10.1177/0748233707072490

Rahman M. F., Siddiqui M. K. J., Jamil C. K. (2000): Inhibition of acetylcholinesterase and different ATPases by a novel phosphorothionate (RPR-II) rat brain. Ecotoxicol. Environ. Saf. 47, 125-129 http://dx.doi.org/10.1006/eesa.2000.1956

Sadowska A. M., Manuel-y-Keenoy B., De Backer W. A. (2007): Antioxidant and anti-inflammatory efficacy of NAC in the treatment of COPD: discordant in vitro and in vivo doseeffects: a review. Pulm. Pharmacol. Ther. 20, 9-22 http://dx.doi.org/10.1016/j.pupt.2005.12.007

Saricaoglu F., Dal D., Salman A. E., Atay O. A., Doral M. N., Salman M. A., Kilinç K., Aypar U. (2005): Effect of low-dose $\mathrm{N}$-acetylcysteine infusion on tourniquet-induced ischaemiareperfusion injury in arthroscopic knee surgery. Acta Anaesthesiol. Scand. 49, 847-851 http://dx.doi.org/10.1111/j.1399-6576.2005.00722.x

Smulders C. J., Bueters T. J., Van Kleef R. G., Vijverberg H. P. (2003): Selective effects of carbamate pesticides on rat neuronal nicotinic acetylcholine receptors and rat brain acetylcholinesterase. Toxicol. Appl. Pharmacol. 193, 139-146 http://dx.doi.org/10.1016/j.taap.2003.07.011

Teimouri F., Amirkabirian N., Esmaily H., Mohammadirad A., Aliahmadi A., Abdollahi M. (2006): Alteration of hepatic cells glucose metabolism as a noncholinergic detoxication mechanism in counteracting diazinon-induced oxidative stress. Hum. Exp. Toxicol. 25, 697-703 http://dx.doi.org/10.1177/0960327106075064

Tietze F. (1969): Enzymic method for quantitative determination of nanogram amounts of total and oxidized glutathione: applications to mammalian blood and other tissues. Anal. Biochem. 27, 502-522 http://dx.doi.org/10.1016/0003-2697(69)90064-5

Uzun F. G., Demir F., Kalender S., Bas H., Kalender Y. (2010): Protective effect of catechin and quercetin on chlorpyrifos-induced lung toxicity in male rats. Food Chem. Toxicol. 48, 1714-1720 http://dx.doi.org/10.1016/j.fct.2010.03.051

Westgard J. O., Poquette M. A. (1972): Determination of serum albumin with the „SMA $12-60$ “ by a bromcresol green dyebinding method. Clin. Chem. 18, 647-653

Xia Z., Kuo K. H., Nagareddy P. R., Wang F., Guo Z., Guo T., Jiang J., McNeill J. H. (2007): N-acetylcysteine attenuates PKCbeta2 over expression and myocardial hypertrophy in streptozotocin-induced diabetic rats. Cardiovasc. Res. 73, $770-782$ http://dx.doi.org/10.1016/j.cardiores.2006.11.033

Yi M. Q., Liu H. X., Shi X. Y., Liang P., Gao X. W. (2006): Inhibitory effects of four carbamate insecticides on acetylcholinesterase of male and female Carassius auratusin vitro. Comp. Biochem. Physiol. C. Toxicol. Pharmacol. 143, 113-116 http://dx.doi.org/10.1016/j.cbpc.2005.12.008

Yousef M. I., El-Demerdash F. M., Kamel K. I., Al-Sahlen K. S. (2003): Changes in some hematological and biochemical indices of rabbits induced by isoflavones and cypermethrin. Toxicol. 189, 223-224 http://dx.doi.org/10.1016/S0300-483X(03)00145-8

Zimet I. (1988): Acetylcysteine: a drug that is much more than a mucokinetic. Biomed. Pharmacother. 42, 513-520

Received: December 10, 2014

Final version accepted: February 6, 2015

First published online: April 30, 2015 